\title{
光伸縮性フォトクロミックポリマー単分子膜の可視化
}

\author{
関隆 広

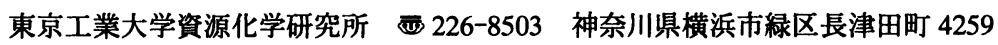

(1997 年 9 月 22 日受理)

\section{Visualization of Photoresponsive Monolayers Comprised of Photochromic Polymers}

\author{
Takahiro SEKI \\ Research Laboratory of Resources Utilization, Tokyo Institute of Technology \\ 4259 Nagatsuta, Midori-ku, Yokohama, Kanagawa 226-8503
}

(Received September 22, 1997)

\begin{abstract}
Photomechanical response of the polymer monolayers having an azobenzene (Az) side chain was successfully visualized by Brewster angle microscopy (BAM) and atomic force microscopy (AFM). In situ BAM observation that covers the sub-millimeter scale range revealed clear photoinduced morphological and rheological changes. By following the photoinduced morphological changes of an isolated single domain, a couple of hitherto unknown properties have been unveiled, for example, non-linearity involved in the film expansion process, intrinsic magnitude of film expansion at zero pressure, dependence on light intensity and so forth. By AFM that observes the ranges of micrometer to nanometer levels, it was found that even on a mica surface, the Az containing monolayer shows a reversible photoinduced film deformation under highly humid conditions. These visualization techniques provided a great deal of complementary unique information which covers the scale ranges between the macroscopic Langmuir trough experiments and scale spectroscopic observations at a molecular level.
\end{abstract}

\section{1. はじめに}

適当な刺激により，有機・高分子材料を任意に伸縮・ 変形する現象は, 人工筋肉の創製, ロボットのソフトア クチュエータ開発，ドラッグデリバリ一等医用分野への 応用, 物質分離システム等への展開に従来より大きな期 待が寄せられている1)。人工的な材料において巨視的な メカニカル作用を分子論的な議論へと結びつけるには, ひとまず系を極端に単純化して検討を進める必要があ る。それには材料の次元を低め, 有機・高分子材料とし て極限の薄膜である界面に形成される二次元単分子膜を 扱うのが最も好都合である。単分子膜系では, 分子運動 や変形の方向性が揃うことから，分子個々の動きが，そ のまま目に見える巨視的レベルでの変化へと直接対応さ せることが可能となる。

E-mail:tseki@res.titech.ac.jp
話を光刺激応答にしぼる。1980 年代の入江らによる 精力的な研究を中心にフォトクロミック単位を導入した 高分子フィルムやゲル材料といった三次元材料の光誘起 伸縮現象は大いに注目を集めた ${ }^{2)}$ 。た時を同じくして, フォトクロミック水面単分子膜のフォトメカニカル効果 に関する研究も盛んに行われだ)。しかしこうした現 象論的に興味深い系む, 分子レベルでの議論と巨視的な 挙動とのスケールギャップを埋めることの困難さから， 今一つ現象の本質に踏み込めず，いずれの研究も影をひ そめることとなった。単分子膜系においてもっぱら行わ れたラングミュア膜天秤を用いた観測だけでは得られる 情報に限界があった。こうした背景から，著者らは顕微 鏡観測による可視化を進めて，フォトクロミック単分子 膜のフォトメカニカル応答現象の正確な理解を進めるこ との必要性を痛感した。

水面上での単分子膜の形態あるいは相状態のその場情 報はケイ光顕微鏡あるいはブリュースター角顕微鏡より 
得られる。これらを用いるとサブミリメータからマイク ロメータレベルの形態観測ができる。さらにごく最近， 著者らはマイカ表面に LB 法で調整した同単分子膜が吸 着水の存在により，光による大きな形態変化を示すこと を原子間力顕微鏡（AFM）により確認した。AFM 観測 では現時点で，その場観測を行うには至っていないが， これにより単分子膜の分子スケールに迫る動的挙動の観 測への道が拓かれることとなった。

Fig. 1 には, 水面単分子膜の光力学効果の観測の手段 がカバーできる情報のスケールを示している。従来から の手段である，ラングミュア膜天秤による目に見える巨 視的範囲での情報と, 紫外可視吸収スペクトルや表面電 位といった分子レベルの変化に係る情報に大きなスケー ルギャッブが存在するが，ここでの BAM および $\mathrm{AFM}$ による 2 つの顕微鏡観測手段が加わることで，これらの ギャップをちようどよく埋めることができる。本稿では 最近得られたアゾベンゼン系ポリマー単分子膜の可視化 についての著者らの成果をまとめたい。他のグループの 関連する優れた報告については, 既にいくつかの解説 ${ }^{3} 5$
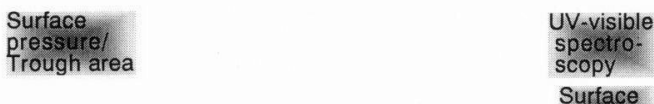
Surface
potentia

\section{BAN}

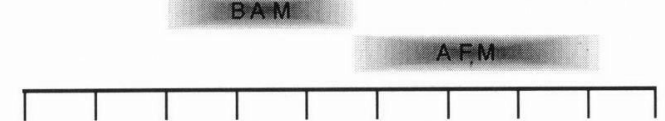

$10^{-1} 10^{-2} 10^{-3} \cdot 10^{-4} 10^{-5} 10^{-6} \quad 10^{-7} \quad 10^{-8} \quad 10^{-9} 10^{-10}$ $\mathrm{mm}$

$\mu \mathrm{m}$

$\mathrm{nm}$

Fig. 1 Tools for observation of photomechanical response of monolayers.
にまとめた。

\section{2. 単分子膜の光誘起マクロサイズ効果}

アゾベンゼン $(\mathrm{Az})$ 単位を側鎖に導入したポリビニ ルアルコール誘導体 6 Azn-PVA（Fig. 2）の水面単分子 膜へ紫外光 $(365 \mathrm{~nm})$ /可視光 $(436 \mathrm{~nm})$ の交互照射を 行うと, 膨張/収縮を繰り返す ${ }^{6 \sim 8)}$ 。

ラングミュア膜天秤を用い, 純水上にてこれら水面単 分子膜の表面圧を $2 \mathrm{mN} / \mathrm{m}$ に保つようにモニターしつ つ, 光照射を行った際の面積変化を Fig. 3 に示す。高分 子誘導体を用いると伸縮過程での膜の崩壊を防ぐことが でき，伸縮過程での再現性はかなりよい。面積変化はア ゾベンゼン単位と主鎖の PVA 部分を結ぶスペーサが長 いものほど変化量が大きく, 炭素数 10 のスペーサの 6 $\mathrm{Az}$ 10-PVA では, 約 3 倍という現在の報告では最も大き な面積膨張と収縮がみられる6)。

光による単分子膜の変形挙動は, 光異性化に伴う Az 単位の界面での動きによるとして理解している(Fig. 4)。 トランス型とシス型の $\mathrm{Az}$ の大きな極性の違いから, $\mathrm{Az}$ 単位が水面と接したり (シス型), 離れたりする（トラ ンス型）というものである6,7)。この説明で, スペーサ が長いものほど変化量が大きいことが理解できるし, Space Filling モデルから期待される分子占有面積の変化 とも良い一致を示している。

光で，ポリマー膜が自ら伸縮することそのものは， ラ ングミュア天秤を用いなくても Fig. 5 に示したような簡 単な装置で確認することができる9)。2つの円形槽を細 い運河でつないだアレイ型の水槽に $6 \mathrm{Az}$ 10-PVA 単分子 膜を作製し，運河にアルミ䈃を浮かべておく。片側の水 槽に紫外光, 逆側に可視光を照射すると, アルミ䇴は運

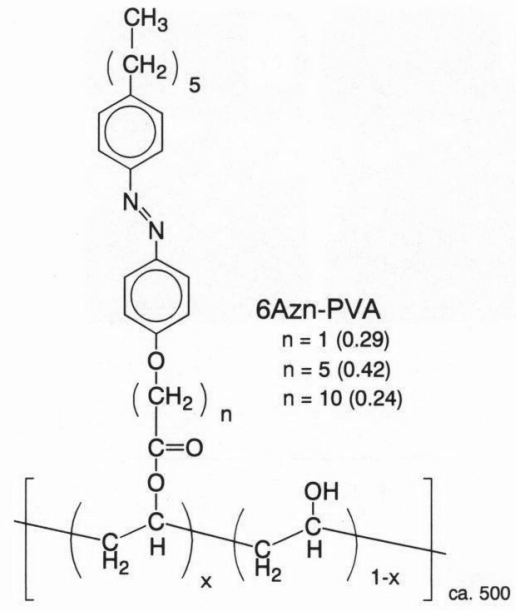

Fig. 2 Chemical structure of $6 \mathrm{Az}$ 10-PVA.

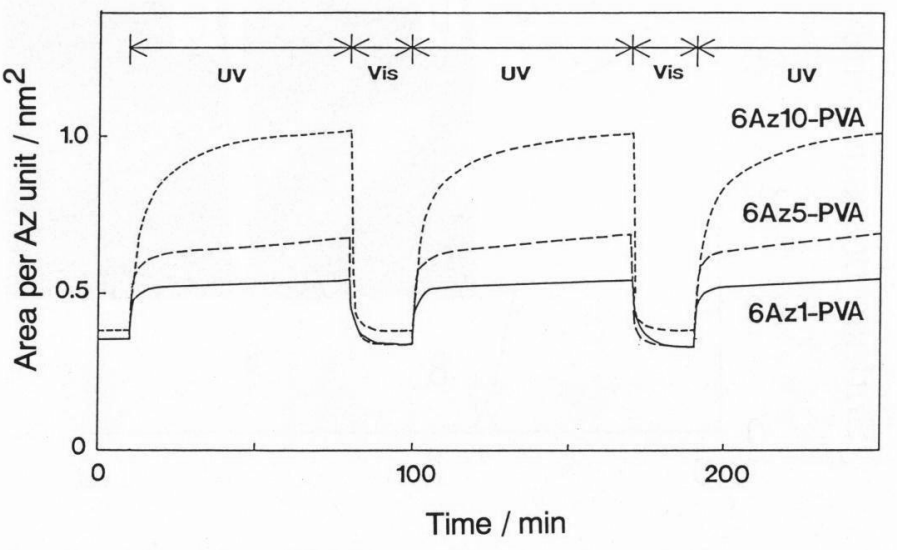

Fig. 3 Photoinduced reversible area changes of $6 \mathrm{Az}$ 10-PVA monolayers on pure water. 
河の上を可視光照射側に素早く(約 $10 \mathrm{~cm} / \mathrm{s}$ ) 移動する。 照射光の波長を逆転させると,アルミ箔は逆方向に動く。 また, 一定の面積を保ちながら光照射を施すと, 膜の伸 縮は表面圧の変化に反映されるが, 表面圧の変化はショ
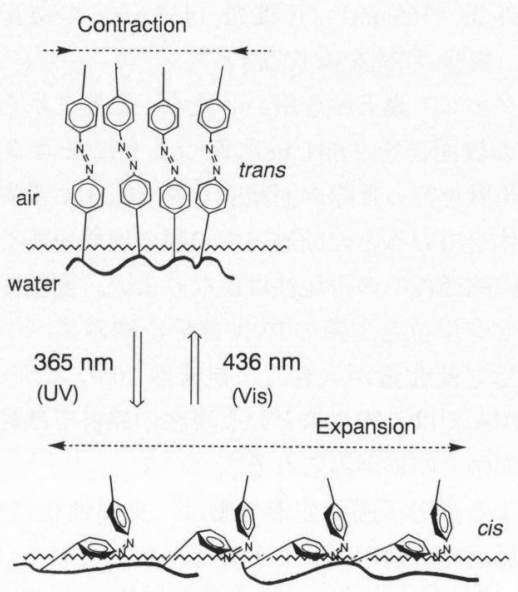

Fig. 4 Supposed mechanism of photoinduced area changes for 6 Azn-PVA monolayers.

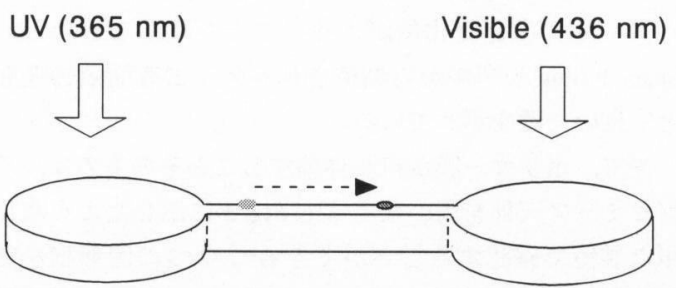

Fig. 5 A simple equipment for photoinduced area changes of monolayer (details, see text).
ウノウ粒の動きの変化で捉えることもできる゙, 7)。

\section{3. 光学顕微鏡によるその場観測}

水面単分子膜の顕微鏡観測の手段として, 1983 年頃 開始されたケイ光顕微鏡 $\left.{ }^{10}{ }^{11}\right)$ と，1991 年発表されたブ リュースター角顥微鏡 $(\mathrm{BAM})^{12}{ }^{13}$ がある。どちらも膜 の物理化学的状態や形態を把握するための重要な手段と して頻繁に用いられている。フォトクロミック単分子膜

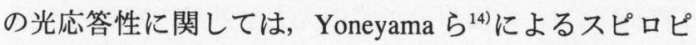
ランを含む混合単分子膜の膨張膜ドメイン形態のケイ光 顕微鏡観測, Ahuja ら ${ }^{15)}$ による Az 系単分子膜の状態観 測, Tabe と Yokoyama ${ }^{16)}$ による Az 系液晶状態単分子膜 の偏光照射による分子配向の動的制御, および, Karthaus $ら^{177}$ によるスチルベン系単分子膜の可逆的光応答結晶化 挙動の観測といった優れた報告がある。

上記の仕事は低分子膜系の物理的状態変化の観測であ るが, 著者らは, 光刺激に応答して面積が変化するポリ マー単分子膜の動的伸縮変化の観測に焦点を絞って BAM による検討を進めた。ケイ光プローブとの相溶性 が悪いであろらポリマー単分子膜系の光伸縮応答に対し ては, ケイ光顕微観測より BAM 観測がより適切であろ らと判断したためである。空気一水界面のブリュースタ 一角で入射した $\mathrm{p}$ 偏光のほとんどは水中へ透過し, 反射 光はほとんど観測されないことから，露出した水面は暗 く観測される。一方, 単分子膜が存在すれば, 水面との 届折率の違いから一部光が反射されるため, これを CCD カメラあるいはビデオカメラで撮影すれば膜の部分は明 るく捉えられ，膜形態変化を可視化観湘できる。

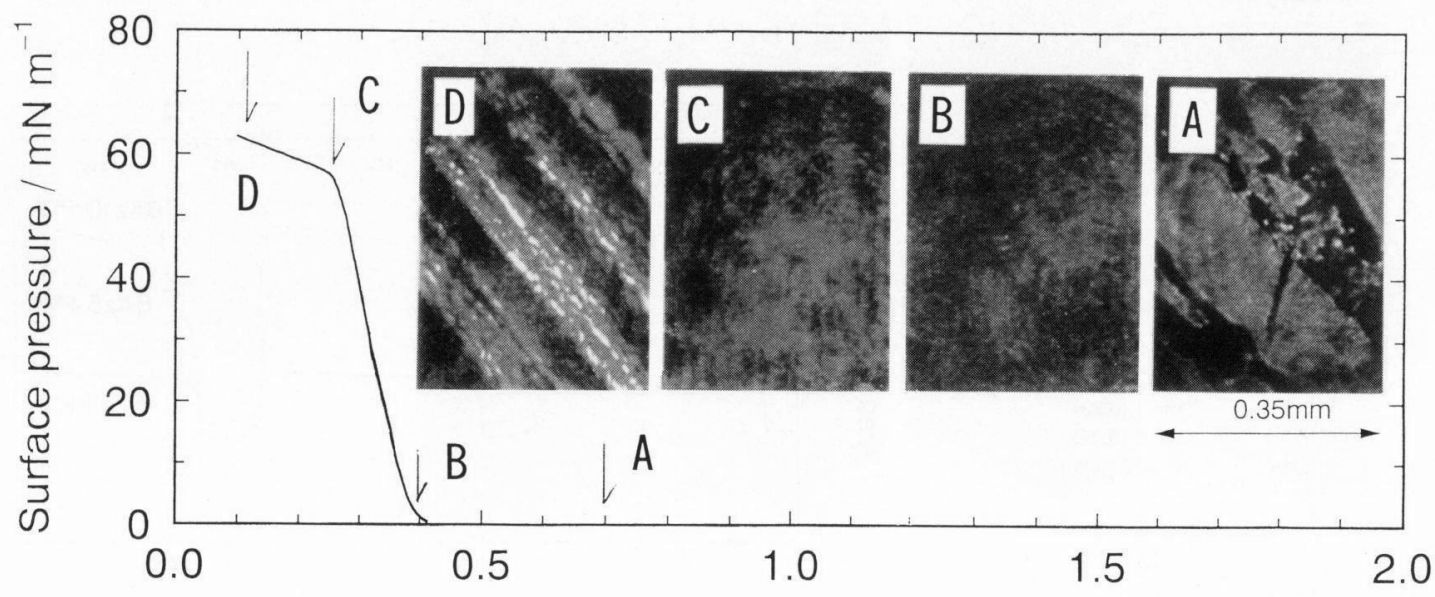

Area per $\mathrm{Az}$ unit / $\mathrm{nm}^{2}$

Fig. 6 BAM images of trans-6 Az 10-PVA monolayer observed upon compression. 


\section{1 圧縮下, 光照射下での膜形態の変化}

6 Azn-PVA 単分子膜形態の基本的な性質として, 圧縮 に伴う膜形態の変化を観測した ${ }^{18)}$ 。一例として Fig. 6 に トランス型の $6 \mathrm{Az}$ 10-PVA 単分子膜の結果を示す。トラ ンス型では展開後水山状のドメインが観測される $(\mathrm{A})$ 。 圧縮に伴いアゾベンゼン単位当たり $0.4 \mathrm{~nm}^{2}$ 付近から表 面圧を生じるがこの付近から露出した水面はほとんど消 える。印刷写真では見えにくいが，ドメインは直ちには 融着せず，加圧により次第に均一化する様子が観測され る $(\mathrm{B} \rightarrow \mathrm{C}) 。 55 \mathrm{mN} / \mathrm{m}$ 付近の崩壊点を越えて圧縮を進 めると, 筋状の崩壊膜が観測される (D)。筋は圧縮方 向に垂直（可動バリアに平行）に伸びており，これはポ リアミド酸のような剛直高分子の単分子膜の崩壊挙動と 似ている ${ }^{19)}$ 。トランス型 $6 \mathrm{Az}$ 10-PVA 膜はドメインは変 形しにくく，針でつつく等による力学的刺激でクラック が生じる剛性の高い固い膜である。一方, 図に示さない が, シス型の $6 \mathrm{Az}$ 10-PVA 単分子膜は崩壊後も含め, 常 に液体様の流動的な膜であることがわかる ${ }^{18)}$

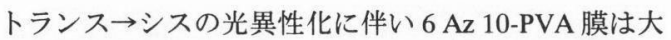
きく流動性が増すことから，紫外光 $\rightarrow$ 可視光照射のサイ クルで, トランス型膜を容易に大面積にて均一化でき る18)。すなわち, ドメイン状小片の集合体である不均一 なトランス型の膜に紫外光照射を施すと膜は高度に均一 化するが，可視光照射でトランス型に戻すと大面積での 均一性を保ったままトランス型へと固化する。脂肪酸単
分子膜では加熱により膜を流動化させ，再び冷却するこ とによって大面積で均一な膜を得る手法が知られている が20)，6 Az 10-PVA 膜では，等温的な光照射の操作で同 様な効果が得られることになる。

Fig. 7 にはトランス型の 6 Azn-PVA 膜で Az 単位当た り約 $0.6 \mathrm{~nm}^{2}$ の面積を与えて, 紫外光照射下, 膜形態の 変化を可視化したものである ${ }^{21}$ 。スペーサ長を変えた膜 におけるこれらの像から, Fig. 3 に示した光による膜膨 張の程度の違いが直接可視化できることがわかる。いず れの膜もトランス型では氷山様のドメインが観測される 固い膜である。紫外光照射によって膨張変形が誘起され るが, 最も面積膨張の小さい $n=1$ では, かなりの露出 した水面を保ったまま流動的となり, 円形のドメインと なる。一方, 最も膨張の大きい $n=10$ では, 最終的に 露出した水面は全くなくなる。 $n=5$ ではその中間の挙 動であり, 露出した水面は残るものの, その面積は $n=$ 1のものよりかなり少ないことがわかる。

\section{2 単分子膜の孤立ドメイン片の追尾観測}

上記のような動的な膜を通常のラングミュア天秤にて 観測するとすぐに顕微鏡視野から外れてしまい，同一の 場所を追いかけることは困難である。そこで可動 X-Y ステージ上にのせたミニトラフを用い, 同一の膜小片を 追尾できる装置を作成した ${ }^{22)}$ 。光照射は底の石英空から 行う。この装置を用いて, トランス型の $6 \mathrm{Az}$ 10-PVA 膜 小片に紫外光照射を施したときの形態変化を BAM 観測
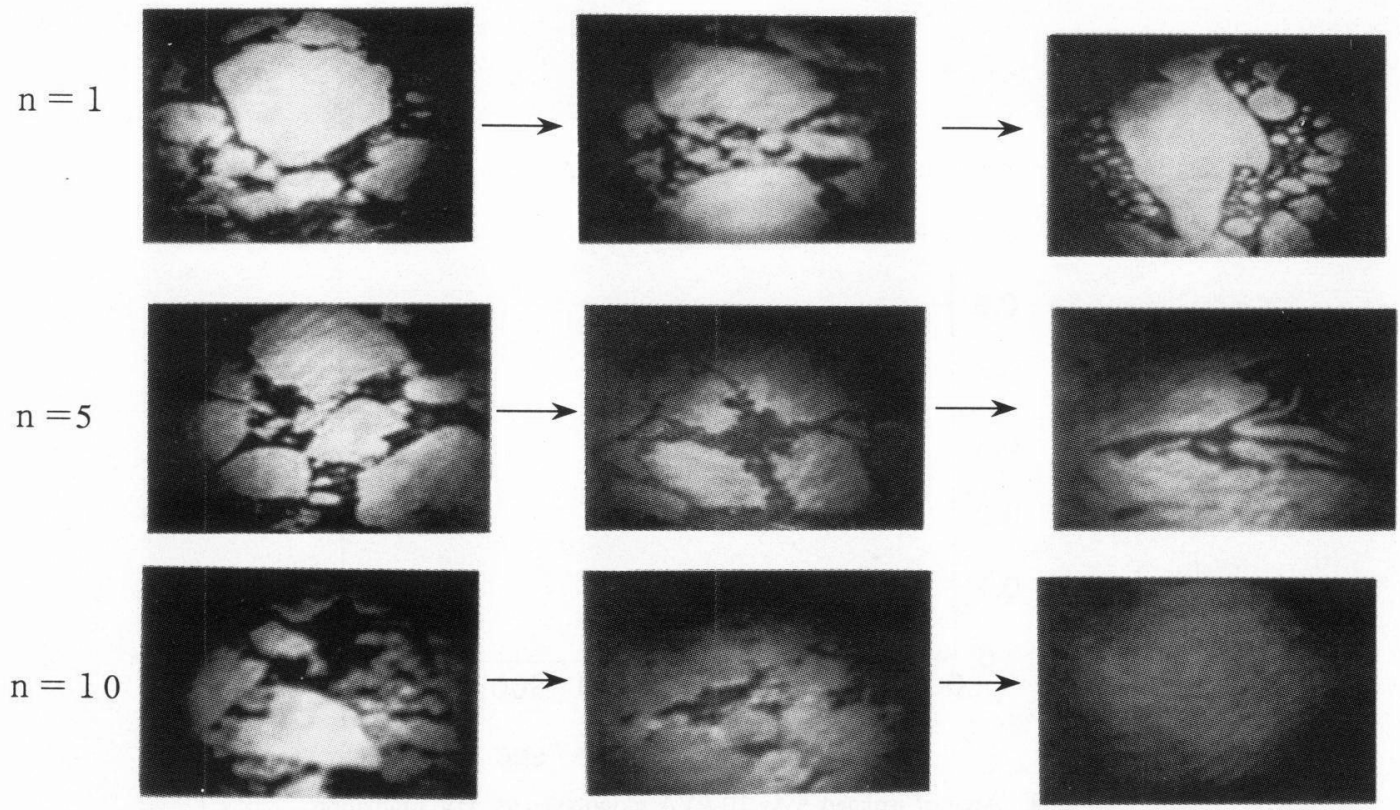

Fig. 7 Direct observation of UV light induced area expansion of 6 Azn-PVA monolayers by BAM. $n$ corresponds to the spacer length of 6 Azn-PVA (see Fig. 2). 
した一例を Fig. 8 に示す。紫外光照射に伴って水面と膜 とのコントラストは低下し膜が広がり, 複雑な形状の輪 郭を持つ膜へと変化していくことがわかる。コントラス トの低下は膜厚あるいは密度の低下による。
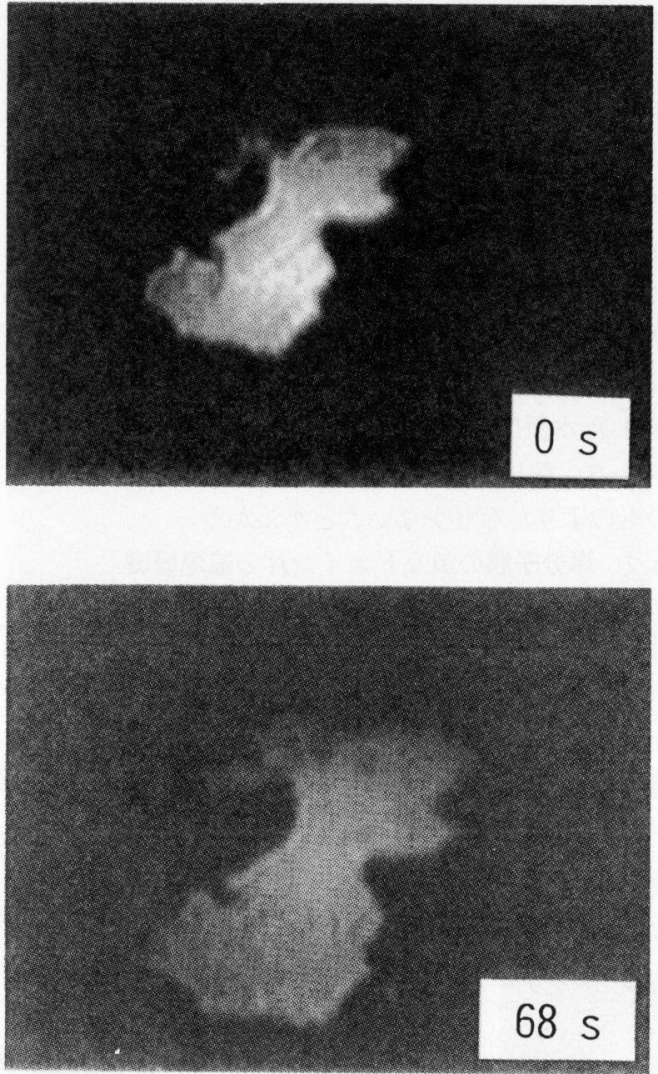

$6 \mathrm{Az}$ 10-PVA 膜小片の輪郭からその面積を評価し，照 射時間とともにプロットしたものを Fig.9 に示す。この 図には, BAM 観測から初めて得られたいくつかの重要 な情報が含まれている。（1）紫外光照射による膜面積の
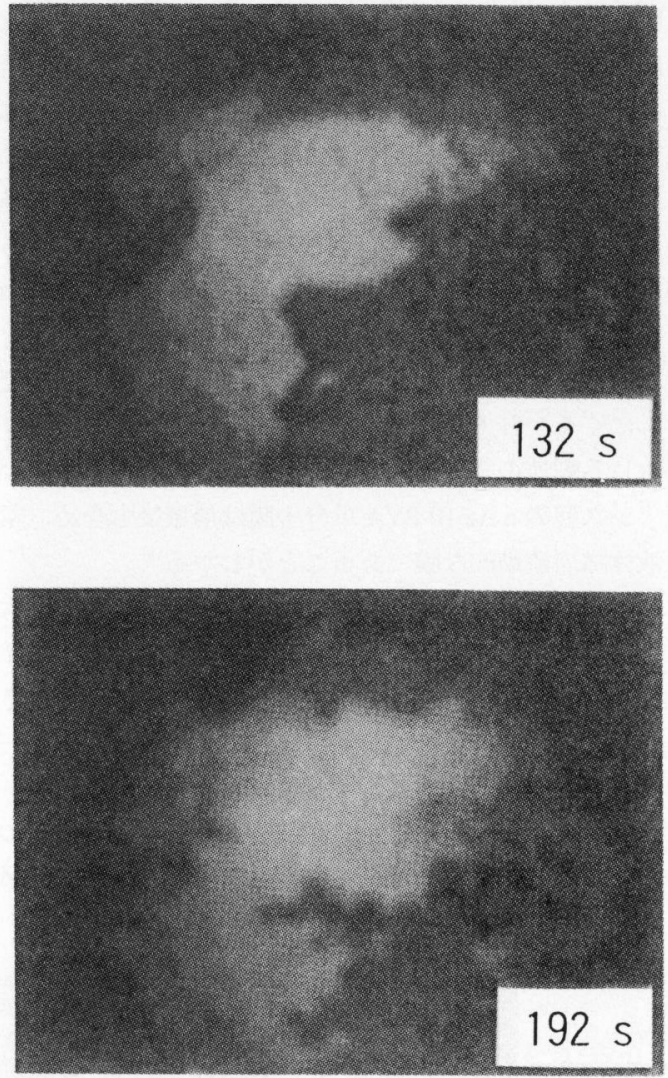

Fig. 8 BAM images monitoring a single isolated $6 \mathrm{Az}$ 10-PVA monolayer upon UV light irradiation.

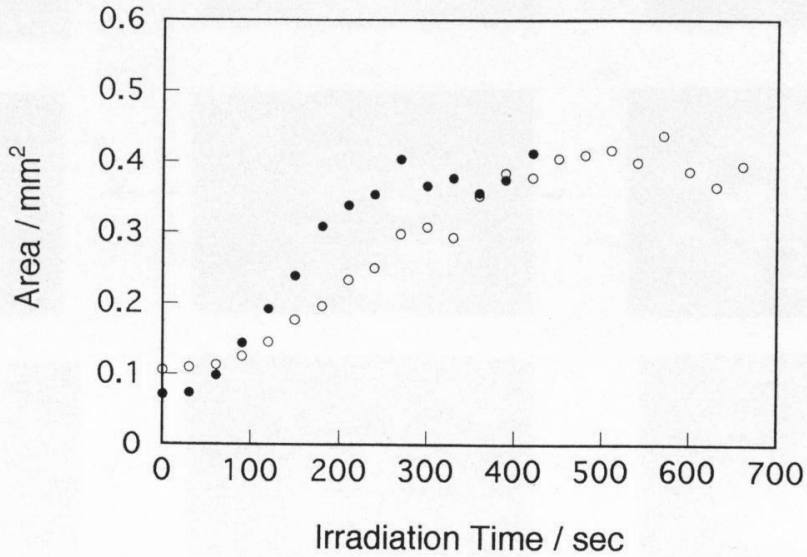

Fig. 9 Area of isolated $6 \mathrm{Az}$ 10-PVA monolayer vs. UV irradiation time. Irradiation intensity: Closed; $0.50 \mathrm{~mW} / \mathrm{cm}^{2}$, open; 0.26 $\mathrm{mW} / \mathrm{cm}^{2}$ 

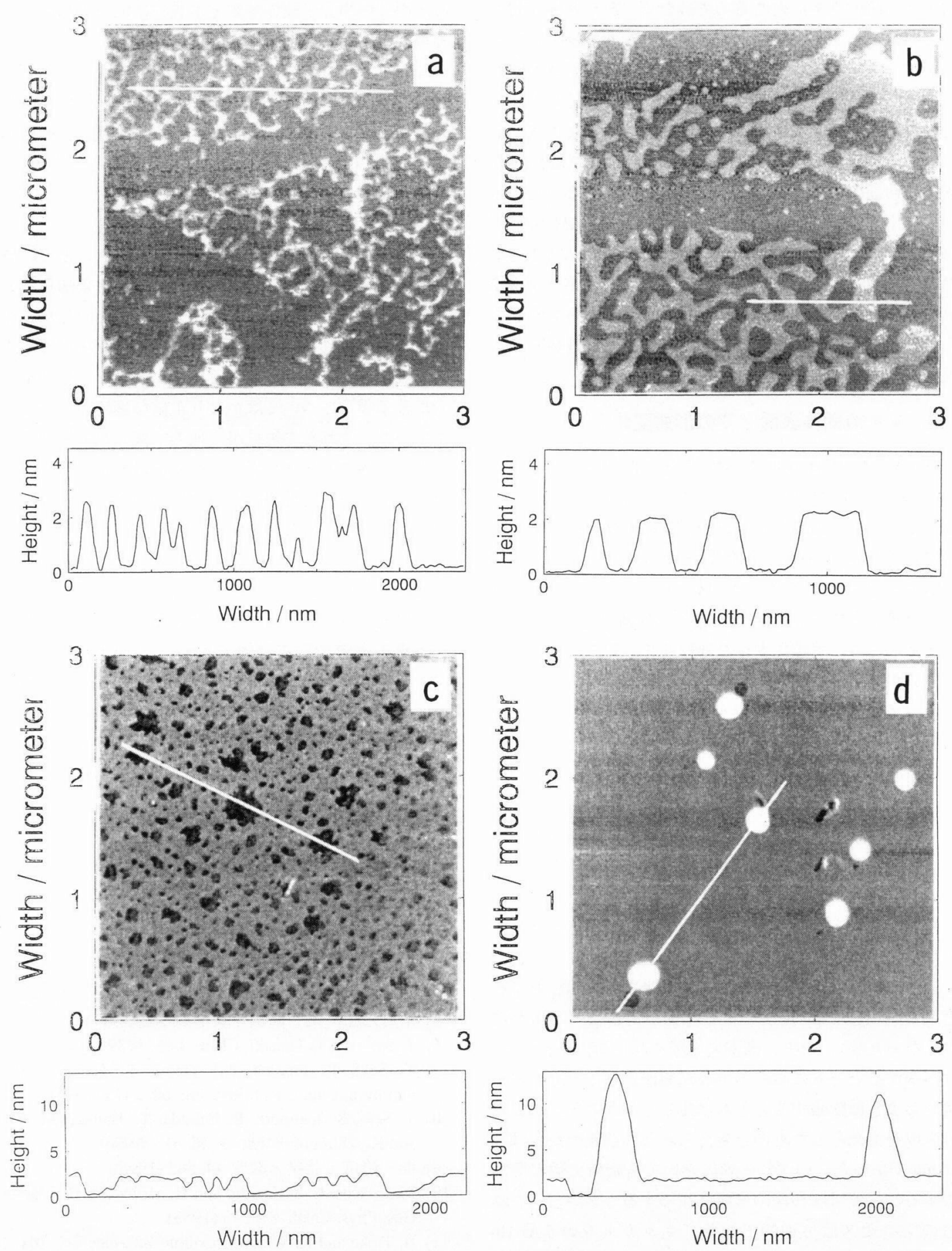

Fig. 10 Photoinduced morphological changes of 6 Az 10-PVA molecular films on mica at high humidity (RH, ca. 100\%) observed by AFM. Top; lower density coverage film (1.2 nm²/Az unit), bottom; higher density coverage film (0.4 $\mathrm{nm}^{2} / \mathrm{Az}$ unit). Before (a and $\mathrm{c}$ ) and after (b and d) UV irradiation. 
増大は，照射直後に起こるのではなく，ある誘導期間を 経て開始される。光異性化そのものは紫外可視吸収スペ クトルの測定から直後から進行しており, 膜面積の增加 は, 光異性化の進行に対して非線形的な現象である（こ の応答非線形性は, その後膜天秤による詳細な再試によ ってより明確に確認された $\left.{ }^{23}\right)$ 。（2）膜面積の最終的な 膨張は初期の 4 5 倍であり, Fig. 3 で示される $2 \mathrm{mN} / \mathrm{m}$ の圧力下で観測された約 3 倍より大きい。BAM 観測で は非圧力下の条件であるため，これが本来の $6 \mathrm{Az} 10$ PVA 膜の面積膨張率を与えている。（3）光照射光量を 2 倍にすると面積変化が見られなくなる時間が約半分とな ることから，少なくともこの条件範囲では光量調節で膨 張速度を正確に制御できることを示している。

\section{4. マイカ固体表面上での形態変化}

著者らは，固体基板上へ移しとった単層の $6 \mathrm{Az} 10$ PVA 膜上でのジアセチレン LB 膜の重合挙動の実験 ${ }^{24)}$ 進める過程で, 湿度变化が重合挙動に顕著な影響を及ぼ すことを突き止めた。高湿度下では固体上の $6 \mathrm{Az}$ 10PVA 単分子膜は形態的な安定性がそしくなるものと考 え, マイカ上でのこの単分子膜の形態観測を AFM にて 行ったところ, 実際に大きな形態変化が観測されること を見いだした（Fig. 10) 25)。

シス型の $6 \mathrm{Az}$ 10-PVA 単分子膜を $0.4 \mathrm{~nm}^{2}$ (ここでは 高密度膜と呼んでおく）と $1.2 \mathrm{~nm}^{2}$ (低密度膜)にてへ き開直後のマイカ上に移しとった。引き上げ直後は均一 な膜であるが，室温相対湿度約 $100 \%$ の条件下にて数 日間放置しておくと，トランス体への熱的な異性化が進 むにつれて, 低密度膜では網目状 (a), 高密度膜では多 数の穴が空いたスポンジ状（c）の形態を与える。すな わち $6 \mathrm{Az}$ 10-PVA 膜はマイカ表面を滑る動きを伴った大 きな形態変化を示すことが判明した。

低密度の膜に高湿度条件下, 紫外光を数時間照射する と網目状の膜 $2 \mathrm{~nm}$ 程度の膜厚を保ったまま, 明らかに 太くなった (b)。一方, 高密度の膜に同じ操作を施すと, 穴が塞がるとともに突起の生成が観測された（d)。穴が 塞がるように膨張するとともに生じた余剩の圧力が突起 の生成をもたらしたものと考えられる。突起の高さは約 $10 \mathrm{~nm}$ であった。いずれの膜においても暗所で数日間放 置することでほぼ初期の形態に復帰することから，これ らのプロセスは可逆的である。マイカ上での $6 \mathrm{Az} 10$ PVA 単分子膜の形態変化は乾燥状態では観測されない。 Beaglehole $~^{26)}$ によると, 室温相対湿度約 $100 \%$ にて約 $2 \mathrm{~nm}$ の吸着水層が形成されることがエリプソメトリー により評価されている。マイカ上での $6 \mathrm{Az}$ 10-PVA 単分 子膜の動きは, 吸着水の働きが不可欠であり, この現象
は水面での単分子膜の挙動と本質的に同一のものである と現在のところ考えている。

なお，マイカ上でのポリイオンコンプレックス型アゾ ベンゼン誘導体単分子膜において, 松本ら ${ }^{27)}$ 類似した 現象を発見して抢り，紫外光/可視光照射による突起の 形成/消滅を観測している。

\section{5. おわりに}

このように，顕微鏡による可視化を行うことで，単分 子膜のフォトメカニカル特性に関して, 従来知られてい なかった数多くの情報が得られることが判明した。ここ では詳しく触れなかったが，紫外可視吸収スペクトル観 測, 表面電位観測も併用することにより ${ }^{23)}$, 当グループ の単分子膜系についてはかなり正確な理解が進んだと考 えている。これらの知見が, 他の二次元単分子膜のメカ ニカル応答にとどまらず, 三次元材料も含めた種々の高 分子メカニカル材料の応答挙動について, その理解へ向 けての一助となることを願っている。

\section{部 辞}

本研究を進めるに当たり，適切なご指導をいただきま した東工大資源研市村國宏教授，BAM および AFM 測 定に多大な努力を払っていただいた關澤英彦氏（現りニ 一), 田中圭介氏（現沖電気）, および装置製作に関わっ ていただいた電総研の横山 浩博士と多辺由佳博士, 東 工大資源研の森野慎也助手に感謝いたします。

\section{文献}

1）長田義仁, S. B. Ross-Murphy：日経サイエンス, 1993 年 7 月号, p. 58.

2) M. Irie: Adv. Polym. Sci. 94, 27 (1990).

3) 関 隆広: 工業材料 42, 75 (1994).

4) 関 隆広 : 化学と工業 48, 839(1995).

5) 市村國宏, 関 隆広 : 表面 35, 63 (1997).

6) T. Seki and T. Tamaki: Chem. Lett. 1739 (1993).

7) T. Seki, R. Fukuda, M. Yokoi, T. Tamaki and K. Ichimura: Bull. Chem. Soc. Jpn. 69, 2375 (1996).

8) T. Seki, K. Ichimura, R. Fukuda, T. Tamaki, M. Yokoi and K. Ichimura: Polym. J. 28, 613 (1996).

9) 関 隆広 : 化学々教育 44, 582 (1996).

10) M. Lösche, E. Sackmann and H. Möhwald: Ber. BunsenGes. Phys. Chem. 87, 848 (1983).

11) B. Tieke and K. Weiss: J. Colloid Interface Sci. 101, 129 (1984).

12) B. Hönig and D. Möbius: J. Phys. Chem. 95, 4590 (1991).

13) S. Henon and J. Meunier: Rev. Sci. Instrum. 62, 936 (1991). 
14) M. Yoneyama, A. Fujii, S. Kasuya, S. Maeda and T. Murayama: J. Phys. Chem. 97, 5124 (1993).

15) R.C. Ahuja, J. Maack and H. Tachibana: J. Phys. Chem. 99, 9221 (1995).

16) Y. Tabe and H. Yokoyama: Langmuir 11, 4609 (1995).

17) O. Karthaus, M. Shimomura, M. Hioki, R. Tahara and H. Nakamura: J. Am. Chem. Soc. 118, 9174 (1996).

18) T. Seki, H. Sekizawa and K. Ichimura: Polym. Commun. 38, 725 (1997).

19) K. Hirano and H. Fukuda: Langmuir 11, 4173 (1995).

20) T. Kajiyama, Y. Oishi, M. Uchida, N. Morotomi, J. Ishikawa and Y. Tanimoto: Bull. Chem. Soc. Jpn. 65, 864 (1992).

21) T. Seki, H. Sekizawa, K. Kudo, Y. Hayashi and K. Ichimura: Mol. Cryst. Liq. Cryst. 294, 47 (1997).
22) T. Seki, H. Sekizawa, S. Morino and K. Ichimura: Joint Symposia "Supermolecules and Nano-Organized Systems," Fukuoka December 5-6 (1996) 予稿集, p.144.

23) T. Seki, H. Sekizawa, S. Morino and K. Ichimura: J. Phys. Chem. B 102, 5313 (1998).

24) T. Seki, K. Tanaka and K. Ichimura: Adv. Mater. 9, 561 (1997).

25) T. Seki, K. Tanaka and K. Ichimura: Macromolecules 30, 6401 (1997).

26) D. Beaglehole, E.Z. Radlinska, B.W. Ninham and H.K. Christenson: Phys. Rev. Lett. 66, 2084 (1991).

27) M. Matsumoto, D. Miyazaki, M. Tanaka, R. Azumi, E. Manda, Y. Kondo, N. Yoshino and H. Tachibana: J. Am. Chem. Soc. 120, 1479 (1998). 